\title{
Determination of the tactical athlete level of a high-performance tennis team and subjective assessment of the coach
}

\author{
Layla Maria Campos Aburachid ${ }^{1}$, Breno Tavares Perdigão Mendes², Tatiane Mazzardo ${ }^{1 *}$,

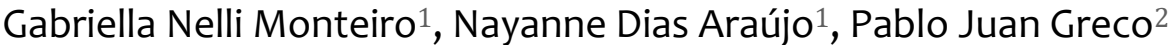

\begin{abstract}
The objective of the study was to evaluate the level of tactical knowledge of a high-performance tennis team, considering gender, age, category, and year in the category, years of practice and participation in competitions. There was also a subjective evaluation by two coaches on the level of athletic performance of their athletes, as well as that of the athletes themselves. In the sample, there were 37 athletes, 23 men and 14 women at ages between 11 and 18 years old $(14.10 \pm 1.90)$. In order to determine the level of athletic performance of the athletes, the test of declarative tactical knowledge (DTK) in tennis was used. The variables to differentiate the level of tactical performance were gender (female achieved better scores: $p=0.004, \mathrm{~F}=2.242$ ), the category (better scores for 18 years old compared to 12 years old: $p=0.007, \mathrm{~F}=$ $4.223)$ and the experience in state competitions $(p=0.042, \mathrm{~F}=3.059)$. It was observed that $73 \%$ of the tennis teams had their level of tactical performance, via DTK, classified as good or very good. In the subjective evaluation, the coach underestimated the tactical level of $48.6 \%$ of his athletes, while $75.7 \%$ of the athletes overestimated their own knowledge. In this study, it was verified that factors like gender, category and experience in state competitions differentiated the level of tactical performance.

Keywords: tennis, decision-making, declarative tactical knowledge.
\end{abstract}

\section{INTRODUCTION}

In the context of sports games, tennis is characterized as a modality or a sport of open motor ability that occurs in an unpredictable environment (Magill, 2011). In order to obtain maximum levels of performance in the training theory, it is advisable to apply technical with tactical training. The psychological condition and the physical preparation, both with tactics and techniques are elements to be developed by a multifactorial formation necessary to get a performance in sports (Verchoshanski, 2006; Platonov, 2008). On this context, tacticaltechnical training is considered as a fundamental content in the formation and development of the athletes from all levels and ages.

However, for an adequate realization of motor and cognitive actions, it is necessary a long process of teaching systematizing, a set of inherent capacities to sports gain (physical, socio- environmental, bio-typological, technical and tactical) (MacMahon \& McPherson, 2009). These capacities help the players lead the actions with efficiency and effectiveness being with constant time pressure. As Treuherz (2005) says, the complete tennis player has an excellent combination of technical, physical and psychological skills, with the capacity to choose the best strategy in different situations of game.

In sports like tennis, the strategic milestone is related to the tactical use (better solution, better decision making) in this moment of the game. In this sense, the tactic is related to the knowledge that the athlete possesses of the game, of the logic of the game. This knowledge is called tactical knowledge (French \& Thomas, 1987).

Soon, the concepts of declarative tactical knowledge (DTK) and procedural tactical knowledge (PTK) first defined by Anderson (1982) stablished the relation between the

\footnotetext{
Manuscript received at September 19 ${ }^{\text {th }} 2017$; Accepted at April 23 2018

${ }^{1}$ Universidade Federal de Mato Grosso, Cuiabá, Brasil.

${ }^{2}$ Universidade Federal de Minas Gerais, Belo Horizonte, Brasil.

* Corresponding author: Rua Dr. Euricles Mota, no 130, Jardim Guanabara, 78010-715

Email: tatimazzardo@hotmail.com
} 
capacities of perception and the decision made by players.

Based on a proposal formulated by Ryle (1949), DTK relates to "what to do" when it comes to a game situation, while PTK relates to "how to do", how to perform motor actions when it comes to a game situation (Chi \& Glasser, 1980; McPherson, 1994; Anderson, Bothell, Byrne, Douglas, Lebiere, \& Quin, 2004).

Empirical studies have been analyzing the factors that can differentiate the level of tactical knowledge, both declarative and procedural, as well as age, experience in practice or competitive time, and the effective training that involves the acquisition of motor skills, such as teaching methods. Among the studies found, only French and Thomas (1987), in basketball, observed differences between ages, in which 11 and 12year-old athletes were better than 8 to 10 -yearold ones in ability to make decisions.

Regarding the experience of the players, some authors point out that there is a strong link between the years of practice and the competitive experience (McPherson \& Thomas, 1989; French et al., 1996; Tenenbaum, Sar-El, \& Bar-Eli, 2000). Significant differences were found in studies comparing experienced players with novices, in which the experts presented better tactical knowledge than novices (French \& Thomas, 1987; McPherson \& Thomas, 1989; French et al., 1996; McPherson, 1999; Domíngues, Arroyo, Gallego, González, \& Álvarez, 2006; McPherson \& Kernodle, 2007). Tenenbaum, Levy-Kolker, Sade and Lidor (1996) have identified that anticipation is one of the cognitive processes that lead to making a decision. Tenenbaum et al. (2000) have confirmed that the anticipation capacity increases from the 6-7 years of experience in years of practice.

The experience in competitions for experienced tennis players was quoted in the studies of McPherson and Thomas (1989), in which the players played an average of fourteen tournaments and Tenenbaum et al. (2000), in which the coaches collaborated in the selection of the players by the history of the performance in national competitions, as well as official rankings in sports federations. In a study conducted by García-Gonzalez, Moreno, Moreno, Gil and Del
Villar (2015), when it comes to experienced tennis players in competitions, those participating in a larger number of competitions, it is pointed out that they presented a higher level of cognitive knowledge, finding significant differences in DTK and PTK amongst different levels of competition. In addition, the relationship between the number of competitions and the level of DTK and PTK proved to be important for intermediate level athletes of the study.

For tennis teaching, there is no referential model of orientation, and as in many other sports, most coaches are former athletes, adopting their own daily practice in the model of their own training, emulating in models of adult tennis players. Fortunately, this panorama has changed, and besides the coaches in a university education in the area, there were non-specialized tennis courses in Brazil too. Therefore, this work strand becomes a potential market for professionals in physical education, the present study aims to collaborate as a pedagogical support for the coaches to perform a better control of the training and, consequently, to improve the specificity of the performance level to achieve with the athletes.

Thus, the present study has the objective to determine the level of tactical knowledge of a high-performance tennis team, considering gender, age, category and year in the category, years of practice, and participation in competitions.

In addition, the coach's subjective assessment to ascertain the level of tactical knowledge of the athletes against the objective scores of the DTK test in tennis was verified, as well as the athletes themselves on their level of tactical knowledge. The studies that used this variable were: in tennis (Tenenbaum et al., 2000; Aburachid, Silva, Guimarães, Morales, \& Greco, 2011), in soccer (Aburachid, Silva, \& Greco, 2013), and five-a-side football (Silva, Aburachid, Camargo, \& Greco, 2014).

Considering what has been shown, the experience in years of practice and the participation in competitions are capable of differing the level of DTK, as the subjective 
evaluation of the coach allows identifying the level of tactical performance of the athletes.

\section{METHOD}

The study is characterized as a descriptive research, with quasi-experimental design, since it seeks to ecological relevance with the greatest threat control to internal validity, recognizing the difficulties in the control of the involved variables (Thomas, Nelson, \& Silverman, 2012). In contrast, this type of research fits well to the objectives to identify the profile of specific subjects regarding the level of skills at the time of collection.

\section{Participants}

A total of 37 young players from the Minas Tennis Club Team, from the city of Belo Horizonte participated in the study, of which 23 were male $(13.50 \pm 2.0)$ and 14 were female (15 \pm 1.30 ), with ages ranging from 11 to 18 years old $(14.10 \pm 1.90)$, in 2010. All the athletes who compete in the amateur national league defending the aforementioned club composed this sample. Besides that, two coaches have participated offering information about their subjective assessment regarding each one of their athletes and the sign test presented proportion in the sample by gender $(p=0.188)$.

In order to join the research, participants have signed an Informed Consent Form (ICF), as well as the term of consent for individuals younger than 18 years old, which contained the objective of the study, the procedures, all the ethics of information of the research, considering having a voluntary participation.

Respecting the norms established by Conselho Nacional de Saúde, a national health council, the project has been approved by Comitê de Ética em Pesquisa (COEP), which is an ethics committee from Universidade Federal de Minas Gerais through Opinion ETIC23/08, in 2010.

\section{Measures}

The DTK test for tennis, validated by Aburachid, Morales and Greco (2013), was chosen to evaluate the DTK of athletes in situations of definition at the back part of the court in the game of simple $(1 \times 1)$. The test consists of 10 actual video scenes that evaluate the cognitive processes of perception and decision-making underlying specific tactical knowledge. In addition, the test aims to contribute to the development of the tactical capacity of practitioners of the sport, and, consequently, offer subsidies to guide the teaching-learning-training process. Like the answer, the volunteers filled a questionnaire for the survey of demographic data: gender, age, category and year in the category, years of practice and participation in competitions.

The evaluation of the subjective variable of coaches about the tactical level of knowledge of the athletes was obtained through a scale from zero (0) to ten (10) points, in which the value 10 represents the maximum of DTK reached in the modality. For the analysis of the descriptive data, this variable was transformed into percentile.

\section{Procedures}

The data collection was individually performed or the acquisition of information regarding the demographic variables (factors). The subjective assessment of the coach took place in isolated collection and for the DTK test in tennis the athletes were grouped in trios.

For each scene, the subject's response has a scale of three possible answers to a decisionmaking that are awarded by quartiles with the most correct response scores for the weakest (ten, six, and three points). The complementation of the response requests, to those who were evaluated, the description of relevant signs contained in the scene that led them to making their decision.

The sequence of each game situation started with the serve, returned and then the scene was frozen for three seconds, moments before the player's decision to end the point. Occlusion of the scene occurs. The subject must make a decision by the player of the scene who is in a previous action to hit the ball with free time of response and later to justify its answer according to the relevant signs of the perception of the action.

The coach's subjective assessment of his athletes' level of tactical knowledge was measured using a scale of 0 to 10 points. It was informed 
that the value 10 on the scale would represent the maximum score for DTK in this modality. For the analysis of the descriptive data, this variable was relativized for the equation of the values with the variable of the DTK test in tennis and subsequent inference of the two dependent variables (objective and subjective DTK).

\section{Statistical analysis}

The data analysis was performed using the SPSS software, version 20.0 for Windows. Applied to the Shapiro-Wilk normality test for decision-making and perception, variables that compose the DTK test, obtaining normal distribution $(\mathrm{p}=0.876)$. Therefore, applied descriptive statistics (absolute and relative) and inferential statistics through the independent test for comparison of the DTK by gender; ANOVA
One-Way for comparing the level of DTK with age, category, year in the category, years of practice and participation in competitions. In order to find out where the differences were amongst the categories, the post hoc of Tukey has been used. The level of significance was set at 0.05 (Dancey \& Reidy, 2006).

\section{RESULTS}

The results were presented following the ordering of the first objective, considering the factors gender, age, year in the category, years of practice and participation in competitions.

Considering the gender, significant statistical differences were found in the level of DTK of the tennis players, with females obtaining better scores than males $(p=0.040, F=2.242)$ as shown below on table 1 .

Table 1

DTK level considering gender, age, category, year in the category, experience and participations in championships

\begin{tabular}{|c|c|c|c|c|c|c|}
\hline & & $\mathbf{N}$ & $\%$ & Mean & SD & $P$ \\
\hline \multirow{2}{*}{ Gender } & Female & 23 & 62.16 & 126.3 & 22.28 & \multirow{2}{*}{$0.040^{*}$} \\
\hline & Male & 14 & 37.84 & 106.6 & 16.96 & \\
\hline \multirow{8}{*}{ Age } & 11 & 5 & 13.51 & 92.4 & 22.86 & \multirow{8}{*}{0.248} \\
\hline & 12 & 3 & 8.11 & 103.63 & 20.78 & \\
\hline & 13 & 7 & 18.92 & 116.28 & 18.58 & \\
\hline & 14 & 7 & 18.92 & 116.54 & 15.17 & \\
\hline & 15 & 4 & 10.81 & 112.42 & 25.82 & \\
\hline & 16 & 3 & 8.11 & 120.96 & 32.95 & \\
\hline & 17 & 5 & 13.51 & 127.76 & 15.91 & \\
\hline & 18 & 3 & 8.11 & 122.6 & 16.11 & \\
\hline \multirow{4}{*}{ Category } & 12 years old & 5 & 13.52 & $92.40^{\mathrm{a}}$ & 22.86 & \multirow{4}{*}{$0.012^{*}$} \\
\hline & 14 years old & 14 & 37.84 & 113.45 & 17.78 & \\
\hline & 16 years old & 9 & 24.32 & 111.95 & 19.43 & \\
\hline & 18 years old & 9 & 24.32 & $129.32^{\mathrm{a}}$ & 17.54 & \\
\hline \multirow{3}{*}{$\begin{array}{c}\text { Year in the } \\
\text { category }\end{array}$} & $1^{\circ}$ year & 19 & 51.35 & 111.62 & 24.32 & \multirow{2}{*}{0.472} \\
\hline & $2^{\circ}$ year & 18 & 48.65 & 116.72 & 17.62 & \\
\hline & 01 to 05 years & 15 & 40.54 & 105.22 & 17.32 & \multirow{3}{*}{0.093} \\
\hline \multirow[t]{2}{*}{ Experience } & 06 to 10 years & 16 & 43.24 & 121.42 & 22.37 & \\
\hline & 11 years onwards & 6 & 16.22 & 115.86 & 21.53 & \\
\hline
\end{tabular}

Note. ${ }^{*} \mathrm{p}<0.05 \mathrm{a} \leq 0.05$

Source: Authors' development

For the second specific age target, which ranged from 11 to 18 years old, there were no significant statistical differences $(\mathrm{p}=0.248 ; \mathrm{F}=$ 0.521) (table 1). Considering the category, there has been found significant statistical differences ( $\mathrm{p}=0.012, \mathrm{~F}=4.223$ ) (table 1 ). It is worth mentioning that the players of junior category, according to the rules of the Brazilian Tennis
Confederation are divided into $12,14,16$, and 18 years old. The post hoc of Tukey showed significant statistical difference only between categories 12 and 18 years old with $\mathrm{p}=0.007$.

As for the year within the category, there was no significant statistical difference in the level of tennis players who were in the first or second year 
of each junior category $(\mathrm{p}=0.472, \mathrm{~F}=0.529)$ (table 1).

Regarding the experience in years of practice, no significant statistical differences were found, with $\mathrm{p}=0.350 ; \mathrm{F}=1.175$. When analyzed in a grouped way with years of practice (from 01 to 05, 06 to 10, and from 11 eleven years of practice onwards), there were also no significant statistical differences with $\mathrm{p}=0.093 ; \mathrm{F}=2.548$ (table 1).

For the participations in championships, five groups were established: never competed, 01 to 05 participations, 06 to 10 participations, 11 to 15 participations and more than 15 participations. These data were collected considering three types of competitions: state, national and international. In state competitions, it was verified that there were significant statistical differences between the level of DTK and participation in championships $(\mathrm{p}=0.042, \mathrm{~F}$ $=3.059$ ). It was not possible to identify where this difference was allocated since the number of subjects per group in participation in state competitions was not proportional. In national and international competitions, no significant statistical differences were found for the level of DTK, with $\mathrm{p}=0.349 ; \mathrm{F}=1.156$ and $\mathrm{p}=0.127$; $\mathrm{F}=1.947$, respectively.

When analyzing the objective result of the DTK test, the subjective assessment of the coach and the self-evaluation there were significant statistical differences for the level of DTK with the evaluation of coach \#1 ( $\mathrm{p} \leq 0.001)$ and coach $\# 2$ ( $\mathrm{p} \leq 0.001)$; both underestimated the athletes' DTK level. Significant statistical difference as found between the DTK level and the selfevaluation ( $p \leq 0.001)$, indicating that athletes, on the other hand, were overestimated in relation to the scores reached in the DTK, according to table 2 .

Table 2

Comparison between the objective DTK level and the subjective evaluations of the coaches and tennis players

\begin{tabular}{lcc}
\hline & Mean & SD \\
\cline { 2 - 3 } Level of DTK & $5.70^{*}$ ab & 1.06 \\
COACH 1 & $4,8^{*}$ & 1,08 \\
COACH 2 & $4,9^{\mathrm{a}}$ & 0,7 \\
AUTOAV & $7,3^{\mathrm{b}}$ & 0,9 \\
Coach 1 & $4.80^{*}$ & 1.08 \\
Coach 2 & $4.90^{\mathrm{a}}$ & 0.70 \\
self-assessment & $7.30^{\mathrm{b}}$ & 0.90 \\
\hline * $\leq$ 0.001 & $\mathrm{a} \leq 0.001$ & $\mathrm{~b} \leq 0.001$ \\
\hline
\end{tabular}

Source: Authors' development

The frequency of grade leveling for the DTK level shown in table 3 indicates that the coaches had a higher percentage of approaching the scores reached in the objective DTK test than the tennis players themselves in their self-assessment.

Finally, the classification of the DTK level is presented below. In this study, the majority of the athletes, $64.9 \%$, were classified as good and no athlete was classified as weak, $27 \%$ classified as regular, and $8.1 \%$ as very good (table 4 ).

Table 3

Descriptive data of coaches' grading frequency and automatic evaluation of tennis players for the DTK system

\begin{tabular}{lcccccc}
\hline & \multicolumn{2}{c}{ Approximate } & \multicolumn{2}{c}{ Underestimate } & \multicolumn{2}{c}{ Overestimate } \\
\cline { 2 - 7 } Coach1 & $\mathrm{n}$ & $\%$ & $\mathrm{n}$ & $\%$ & $\mathrm{~N}$ & $\%$ \\
Coach 2 & 14 & 37.8 & 19 & 51.4 & 4 & 10.8 \\
Self-assessment & 16 & 43.2 & 17 & 45.9 & 4 & 10.8 \\
\hline
\end{tabular}

Table 4

Classification of tennis players' CTD level

\begin{tabular}{lccc}
\hline & $\mathrm{N}$ & $\%$ & Mean $(\mathrm{SD})$ \\
\cline { 2 - 4 } Regulate & 10 & 27 & $88.21 \pm 9.34$ \\
Good & 24 & 64.9 & $121.23 \pm 12.49$ \\
Very good & 3 & 8.1 & $151.96 \pm 4.67$ \\
\hline
\end{tabular}

\section{DISCUSSION}

The aim of the study was to evaluate the tactical knowledge of a high-performance tennis team and to analyze a subjective assessment of the coach on the level of athletic performance of 
their athletes and the athletes themselves on their knowledge.

The results show that the gender variable, in this study, statistically differed the level of DTK of the tennis players, pointing out better scores for the female gender. However, it refutes the findings of Greco et al. (2002) in volleyball, which analyzed decision-making and declarative knowledge of participants in a national competition - "Jogos da Esperança - 2001".

When considering the age of the tennis players, the result coincides with the studies of McPherson and Thomas (1989), French, Spurgeon and Nevett (1995), French et al. (1996), Tenenbaum et al. (1996), McPherson (1999), Tenenbaum et al. (2000), Domíngues et al. (2006), McPherson and Kernodle (2007), Aburachid, Silva and Greco (2014). It points out that age is not considered one of the factors influencing tactical knowledge, except for the study by French and Thomas (1987) and Gil, Moreno, García-González, Moreno and Del Villar (2012), the difference can be derived from variables such as: years of practice and competitive experience.

Regarding the category of the athlete, this study showed a significant difference between the categories of 12 and 18 years old. However, when considering the year in the category (first or second) the analysis did not statistically defer. As an alternative hypothesis, based on studies of the effect of relative age, we expected the opposite since tennis players in the second year of the category have better competitive results, have competed in more tournaments, and generally are the ones who present the best results in competitions. However, this study corroborates the findings of Aburachid et al. (2014) who also did not find differences in this comparison.

The findings of this study, considering the experience in years of practice, corroborate with the studies of Greco et al. (2012) who did not find significant differences between the DTK and the years of practice of the participants of their studies. The exceptions were found in the study by García-González et al. (2012), who pointed out that the experience level of the players had considerable effect on the tactical knowledge of pre-professional athletes in relation to intermediate ones. They were also present in the study by Aburachid et al. (2014), who affirms that from six years of practice on, the DTK score was higher for athletes who participated in a greater number of competitions.

When considering the athletes' DTK level and participation in championships, the results showed that there were significant differences only for state competitions, while for national and international competitions the results did not statistically defer. These findings corroborate with the studies by Aburachid et al. (2014) and García-González et al. (2015) that did not obtain significant results for the level of DTK and participation in national championships. Reinforcing the findings, the latest study found to compose the discussion is by Kumar (2016) who verified the effect of locus of control of university athletes practicing racket sports (ball badminton, badminton and table tennis) who participated in national and international championships. No significant differences in locus of control of the athletesbetweenboth levels of competition were observed.

Considering the coach's subjective assessment, these findings corroborate with the studies of Aburachid et al. (2011) reported that coaches underestimated their athletes' DTK by $41.5 \%, 32 \%$ overestimated, and that $26.5 \%$ approached their assessment of the score reached in the objective test. The study by Aburachid et al. (2013) in soccer, contrasts with the present study since it computed that coaches who underestimated the score of DTK in $89.6 \%$ of their athletes.

As proposed by Aburachid et al. (2014), tennis players are classified by the DTK test for tennis as weak, regular, good and very good. Since in the present study most of the athletes were classified as good, these findings corroborate Silva et al. (2014) revealed in her five-a-side football study that the athletes belonging to the winning group in the championship presented a higher frequency of the "good" classification (55\%). 


\section{CONCLUSION}

After the presentation and discussion of the results, it was possible to determine the level of tactical knowledge of tennis players, and to identify that the female tennis players showed superior results than the male ones. The players in the category of 18 years old were tactically better than the players in the category of 12 years old, and that the experience in state competitions was also able to differentiate the level of DTK. The factors age, year in the category, years of practice, and experience in national tournaments and international did not show differences in the level of income of tactical players.

For the subjective evaluation, the two coaches, \#1 and \#2 underestimated their athletes' DTK value in relation to the achieved score and athletes. On the other hand, overestimated the value of DTK in relation to their achieved score in this study. Finally, the coaches came closer in their assessment of the score achieved in the test than their respective athletes did.

The results of the study indicate pedagogical relevance for the area. However, there are other factors, not only DTK, that are relevant to the teaching-learning-training process, such as the knowledge process and communication capacity (Balbinotti, 2009).

\section{Limitations of the study}

- Difficulty in making financial resources for data collection in other Tennis clubs in the state available.

- Difficulty in reconciling the competitive schedule of the tennis players so that the coaches can make their time available for collection.

- More studies present to be necessary with the analyzed variables for confirmation of the found results.

These factors limited the number of volunteers who have volunteered to perform the DTK test in tennis.

Acknowledgments:

Nothing to declare.
Conflict of interests:

Nothing to declare.

Funding:

Nothing to declare.

\section{REFERENCES}

Aburachid, L. M. C., Silva, S. R., Guimarães, G. A., Morales, J. C. P., \& Greco, P. J. (2011). Nível de Conhecimento Tático Declarativo e Avaliação Subjetiva dos Treinadores no Tênis. In: $3^{\circ}$ Congresso Internacional de Jogos Esportivos Coletivos, 2011, Porto. Revista Portuguesa de Ciências do Desporto, 11, 32.

Aburachid, L. M. C., Morales, J. C. P., \& Greco, P. J. (2013). Test Validation Process of Tactical Knowledge in Tennis: the Influence of Practice Time and Competitive Experience. International Journal of Sports Science, 3(1), 13-22. doi:10.5923/j.sports.20130301.04

Aburachid, L. M. C., Silva, S. R., \& Greco, P. J. (2013). Nível de conhecimento tático de jogadores e avaliação subjetiva dos treinadores de futebol. Revista Brasileira de Futsal e Futebol, Edição Especial: Pedagogia do Esporte, 5(18), 322-330.

Aburachid, L. M. C., Greco, P. J., \& Silva, S. R. (2014). A influência da prática esportiva sobre o conhecimento tático no tênis. Revista da Educação Física, 25(1), 15-22. doi:10.4025/reveducfis.v25i1.18703

Anderson, J. R. (1982). Acquisition of Cognitive Skill. Psychological Review, 89, 369-406.

Anderson, J. R., Bothell, D., Byrne, M. D., Douglas, S., Lebiere, C., \& Quin, Y. (2004). An integrated theory of the mind. Psychological Review, 111(4), 1036-1040.

Balbinotti, C. (2009). O ensino do tênis: novas perspectivas de aprendizagem. ( $\left.1^{\mathrm{a}} \mathrm{ed}\right)$. Porto Alegre: Artmed.

Chi, M. T. H., \& Glaser, R. (1980). The measurement of expertise: analysis of the development of knowledge and skill as a basis for assessing achievement. In: Baker, E. L., \& Quellmalz E. S. (Eds.). Educacional Testing an Evaluation. Beverly Hills, 37-47.

Dancey, C. P., \& Reidy, J. (2006). Estatística sem matemática para a psicologia: usando SPSS para Windows. Porto Alegre: Artmed.

Domíngues, A. M., Arroyo, M. P. M., Gallego, D. I., González, L. G., \& Álvarez, F. V. (2006). Estudio del conocimiento declarativo en función de la experiencia y de la edad en jugadores jóvenes de voleibol. Cultura, Ciencia y Deporte, 3(5), 73-80. doi: $10.12800 / \mathrm{ccd}$

French, K., \& Thomas, J. (1987). The relation of knowledge development to children's basketball performance. Journal of Sport Psychology, 9, 15-32.

French, K. E., Spurgeon, J. H., \& Nevett, M. E. (1995). Expert-novice differences in cognitive and skill execution components of youth baseball 
performance. Research Quarterly for Exercise and Sport, 66 (3), 194-201.

French, K. E., Nevett, M. E., Spurgeon, J. H., Graham, K. C., Rink, J. E., \& McPherson, S. L. (1996). Knowledge representation and problem solution of expert and novice youth baseball players. Research Quarterly for Exercise and Sport, 67(4), 386-395.

García-González, L., Moreno, A., Moreno, M. P., Iglesias, D., \& Del-Villar, F. (2012). Tactical knowledge in tennis: a comparison of two groups with different levels of expertise. Perceptual $\mathcal{E}$ Motor Skills: Exercise \& Sport, 115(2), 567-580.

García-González, L., Moreno, A., Moreno, M. P., Gil, A., \& Del-Villar, F. (2015). The relationship between quantity and level of competition, and cognitive expertise in Spanish tennis players. Kinesiology, 47(1), 91-99.

Gil, A., Moreno, M. P., García-González, L., Moreno, A., \& Del Villar, F. (2012). Analysis of declarative and procedural knowledge in volleyball according to the level of practice and players' age. Perceptual $\mathcal{E}$ Motor Skills: Exercise \& Sport, 115(2), 632-644.

Greco, P. J., Canabrava, C. M., Castro D'ávila, R. C., Ferreira Filho, E., Gomes, M. V. C., Miranda, G., Pereira Lima, C., Santos De Oliveira, M., Silva, S. A, Oliveira Junior, T. F., Coelho De Souza, P. R., Pena Couto, B., Matias Da Silva, C. J. A., \& Campos, P. (2002). Análise do nivel de conhecimento e rendimento técnico-tático. In: Silami Garcia, E., \& Moraes, L. C. (org). Resultado das Avaliações da Olimpíada Colegial Jogos da Esperança 2001. Poços de Caldas, 121-152.

Greco, P. J. (2006). Conhecimento tático-técnico: eixo pendular da ação tática (criativa) nos jogos esportivos coletivos. Revista Brasileira de Educação Física e Esporte, 20, 210- 212.

Greco, P. J., Aburachid, L. M. C., Souza, P. R. C., Hornestam, J. F., \& Mortimer, L. M. (2012). Conhecimento tático declarativo no tênis: classificação e comparação em relação à formação acadêmica e tempo de prática. Revista Mineira de Educação Física, 1(ES), 316-326.

Kumar, R. (2016). Effect of locus of control among various games at different level of participation. International Journal of Physical Education, Sports and Health, 3(6), 190-192.
Magill, R. (2011). Aprendizagem motora. Conceitos e Aplicações ( $8^{\mathrm{a}}$ ed). São Paulo: Phorte.

MacMahon, C., \& McPherson, S. L. (2009). Knowledge base as a mechanism for perceptual-cognitive tasks: Skill is in the details! International Journal of Sport Psychology, 40, 565-579.

McPherson, S. L., \& Thomas, J. R. (1989). Relation of knowledge and performance in boys' tennis: age and expertise. Journal of experimental child psychology, 48(2), 190-211.

McPherson, S. L. (1994). The development of sport expertise: Mapping the tactical domain. Quest, 46, 223-240.

McPherson, S. L. (1999). Tactical differences in problem representation sand solutions in collegiate varsity and beginner female tennis players. Research Quarterly for Exercise and Sport, 70(4), 369-384.

McPherson, S., \& Kernodle, M. (2007). Mapping two new points on the tennis expertise continuum: Tactical skills of adult advanced beginner sand entry-level professionals during competition. Journal of Sports Sciences, 25(8), 945-959.

Platonov, V. N. (2008). Tratado Geral do Treinamento Desportivo. São Paulo: Phorte.

Ryle, G. (1949). The concept of mind. London: Hutchingson.

Silva, S. R., Aburachid, L. M. C., Camargo, R. D., \& Greco, P. J. (2014). Nível de conhecimento tático e perfeccionismo no futsal. Revista Brasileira de Ciências do Esporte, Florianópolis, 36(2), 774-788.

Tenenbaum, G., Levy-Kolker, N., Sade, S., \& Lidor, R. (1996). Anticipation and confidence of decisions related to skill performance. International Journal of Sport Psychology, 27(3), 293-307.

Tenenbaum, G., Sar-El, T., \& Bar-Eli, M. (2000). Anticipation of ball location in low and high-skill performers: a developmental perspective. Psychology of Sport and Exercise, 1 (2), 117-128.

Thomas, J. R., Nelson, J. K., \& Silverman, S. J. (2012) Métodos de Pesquisa em Atividade Física (6 ${ }^{\mathrm{a}}$ ed). Porto Alegre: Artmed.

Treuherz, R. M. (2005). Tênis: técnicas e táticas de jogo: preparação estratégica, mental, física, nutricional ( $1^{\mathrm{a}}$ ed). São Paulo: Alaude.

Verchoshanski, Y. (2006). Os horizontes de uma teoria e metodologia científica do treino desportivo. Lisboa: Revista Treino Desportivo. 